\title{
Curcumin sensitizes Epstein-Barr-immortalized lymphoblastoid cell lines to inorganic arsenic toxicity
}

\author{
MACARIO MARTÍNEZ-CASTILLO ${ }^{1}$, GABRIELA CRUZ-ROBLEDO ${ }^{1,2}$, \\ ARACELI HERNÁNDEZ-ZAVALA ${ }^{1}$ and EMILIO J. CÓRDOVA ${ }^{2}$ \\ ${ }^{1}$ Section of Research and Postgraduate, Superior School of Medicine, National Institute Polytechnique, \\ Casco de Santo Tomás, Mexico City 11350; ${ }^{2}$ Oncogenomics Consortium Laboratory, National Institute of \\ Genomic Medicine, Clinic Research, Arenal Tepepan, Mexico City 14610, Mexico
}

Received September 24, 2020; Accepted February 23, 2021

DOI: $10.3892 / \mathrm{etm} .2021 .10304$

\begin{abstract}
Chronic exposure to inorganic arsenic (iAs) through contaminated drinking water is an important health problem in certain countries. The use of phytochemicals such as curcumin has recently emerged as an alternative strategy for preventing cellular damage caused by iAs. The Epstein-Barr virus (EBV) affects $\sim 90 \%$ of the population and experimental evidence suggested that curcumin mediates cytotoxicity against EBV-infected cells. Due to the potential for an interaction of these factors, the aim of the present study was to evaluate the effect of this phytochemical on iAs-related toxicity in EBV-infected cells. Two independent EBV-immortalized human lymphoblastoid cell lines (LCLs) were used as the model. The cell lines were first incubated with increasing concentrations of curcumin or iAs for 24 and $15 \mathrm{~h}$, respectively, to determine the individual effects of each exposure on cell death. In the next experiment, cell cultures were pre-incubated with $5 \mu \mathrm{M}$ curcumin for $9 \mathrm{~h}$ prior to treatment with $10 \mu \mathrm{M}$ iAs for $15 \mathrm{~h}$, followed by evaluation of cell death and the cell cycle profile via flow cytometry. The results indicated that individual treatment with either curcumin or iAs induced cell death in a concentration-dependent manner. Furthermore, curcumin pre-treatment enhanced iAs-induced cell death and promoted cell cycle arrest in G1 phase. Taken together, these results suggested that curcumin sensitizes EBV-positive LCLs to the cytotoxic effects of iAs.
\end{abstract}

\section{Introduction}

Inorganic arsenic (iAs) is a natural pollutant found in the air and soil, as well as dissolved in groundwater. The main source

Correspondence to: Dr Emilio J. Córdova, Oncogenomics Consortium Laboratory, National Institute of Genomic Medicine, Clinic Research, 4,809 Periférico Sur, Arenal Tepepan, Mexico City 14610, Mexico

E-mail: ecordova@inmegen.gob.mx

Key words: curcumin, inorganic arsenic, Epstein-Barr virus, chemosensitizing of human exposure to iAs is through contaminated drinking water and the maximum allowed limit established by the World Health Organization for iAs in drinking water is $10 \mu \mathrm{g} / 1$ (1). However, an estimated 500 million individuals worldwide still are exposed to high concentrations of iAs, ranging from 400 to $25,000 \mu \mathrm{g} / \mathrm{l}$ (2). Chronic exposure to iAs through contaminated drinking water may lead to non-malignant disorders and to various types of cancer, including bladder, prostate, lung and skin (3). For this reason, the presence of this metalloid in drinking water has been recognized as a significant global health issue (4).

Recently, the use of natural compounds with chemopreventive properties has been explored as a way to reduce iAs-related cellular damage. Curcumin is a phytochemical with potent antioxidant properties against a variety of environmental and intracellular hazards, including iAs (5). Curcumin is consumed worldwide, mainly through using turmeric as a spice. This spice is common in traditional dishes of India, including curry, and is also used as a food colorant and preservative (6). In certain regions such as India, the population normally consumes around $60-100 \mathrm{mg}$ of curcumin per day without any apparent adverse health effects (7). As a chemopreventive compound, curcumin reduces the generation of oxidative stress and DNA damage associated with iAs exposure in different cell types, including keratinocytes, lung cells and lymphocytes (8-10). Of note, the ability of curcumin to mitigate iAs-related DNA damage has been demonstrated in circulating lymphocytes obtained from individuals chronically exposed to iAs-contaminated drinking water $(11,12)$.

Epstein-Barr virus (EBV) belongs to the $\gamma$-herpesvirus family and is among the most prevalent human viruses, affecting $~ 90 \%$ of the population worldwide (13). Although EBV infection has been associated with several human diseases, including infectious mononucleosis and Burkitt's lymphoma, in most cases, infected individuals remain asymptomatic $(13,14)$. It is worth noting that in cellular models derived from gastric and nasopharyngeal carcinomas that are positive for EBV, curcuminoids have higher toxicity (15). Similarly, experimental treatment with curcumin promoted apoptosis in EBV-related Hodgkin's and Burkitt's lymphoma cells $(16,17)$. Furthermore, curcumin promotes apoptosis in EBV-immortalized lymphoblastoid cell lines (LCLs) $(18,19)$. 
These results suggest that EBV infection may influence the chemopreventive properties exerted by curcumin against iAs-induced toxicity. Thus, in the present study, two independent EBV-immortalized LCLs were used to evaluate whether the presence of EBV may modify the protective properties of curcumin against the cytostatic and cytotoxic effects of iAs. The results suggested that curcumin pre-treatment sensitized LCLs to iAs-associated toxicity, induced a slight proportion of G1 phase arrest and promoted cell death.

\section{Materials and methods}

Cell culture and reagents. The lymphoblastoid-derived cell lines CL-45 and CL-49 had been generated by EBV immortalization of peripheral blood mononuclear cells obtained from non-related healthy Mexican-mestizo donors, as described in previous studies by our group $(20,21)$. The cell lines were cultured in RPMI-1640 medium supplemented with $10 \%$ fetal bovine serum, 1\% L-alanyl-L-glutamine (GlutaMax 100x), $1 \%$ non-essential amino acids and $1 \%$ antibiotic-antimycotic (10,000 U/ml penicillin and $10 \mathrm{mg} / \mathrm{ml}$ streptomycin). All cell culture reagents were purchased from Gibco (Thermo Fisher Scientific, Inc.). Cells were cultured at $37^{\circ} \mathrm{C}$ in a humidified atmosphere with $5 \% \mathrm{CO}_{2}$. Sodium arsenite $\left(\mathrm{NaAsO}_{2}\right)$ as the iAs and curcumin were purchased from Sigma-Aldrich (Merck KGaA) and dissolved in dimethyl sulfoxide (DMSO) (Sigma-Aldrich; Merck KGaA) or nuclease-free water (Sigma-Aldrich; Merck KGaA) to obtain 20 and $50 \mathrm{mM}$ stock solutions, respectively. Curcumin and iAs stocks were protected from light and aliquots were maintained at $-20^{\circ} \mathrm{C}$ until use.

Cell treatments. CL-49 cells were seeded at a density of 200,000 cells $/ \mathrm{ml}$ in $4 \mathrm{ml}$ of complete growth medium and allowed to grow for $24 \mathrm{~h}$ prior to incubation with different concentrations of curcumin $(5,10$ or $15 \mu \mathrm{M})$ for $24 \mathrm{~h}$ or iAs $(5$, 10 or $20 \mu \mathrm{M}$ ) for $15 \mathrm{~h}$. In the case of iAs, the incubation time was selected considering a $9 \mathrm{~h}$ pre-treatment with curcumin followed by the $15 \mathrm{~h}$ of iAs treatment, which corresponds to a total incubation time of $24 \mathrm{~h}$, the approximate duration time of cell cycle in LCL. For time-response assays, CL-49 cells were treated with $5 \mu \mathrm{M}$ curcumin for 12,18 or $24 \mathrm{~h}$. As a negative control, cell cultures were treated with the respective vehicles used with curcumin ( $0.1 \%$ DMSO) and $\mathrm{iAs}\left(0.1 \% \mathrm{H}_{2} \mathrm{O}\right)$ for $24 \mathrm{~h}$ in the concentration-response and time-response assays. For the pre-treatment assays, $8 \times 10^{5}$ CL-45 and CL-49 cells were grown for $24 \mathrm{~h}$ and treated with $5 \mu \mathrm{M}$ curcumin for $9 \mathrm{~h}$. Subsequently, the culture medium with curcumin was removed and the cells were washed with $20 \mathrm{ml}$ of $1 \mathrm{X}$ PBS. The cells were then re-cultured in fresh culture medium and treated with $10 \mu \mathrm{M}$ iAs for a further $15 \mathrm{~h}$. Similar washing and re-seeding protocols were used for the following individual treatments groups: i) In the vehicle control group, cell cultures were pre-treated with $0.1 \%$ DMSO for $9 \mathrm{~h}$, followed by $15 \mathrm{~h}$ with $0.1 \%$ nuclease-free water; ii) curcumin treatment alone included incubation of cell lines with $5 \mu \mathrm{M}$ curcumin for $9 \mathrm{~h}$ followed by $0.1 \% \mathrm{H}_{2} \mathrm{O}$ for $15 \mathrm{~h}$; and iii) in the iAs-only group, LCLs were pretreated with $0.1 \%$ DMSO for $9 \mathrm{~h}$ and then incubated with $10 \mu \mathrm{M}$ iAs for $15 \mathrm{~h}$.
Cell death assay. After the treatments, LCLs were harvested and cell death levels determined using the LIVE/DEAD ${ }^{\circledR}$ Fixable Dead Cell Stain kit (Thermo Fisher Scientific, Inc.) according to the manufacturer's protocol. This assay is based on the use of a cell-impermeable fluorescent dye that reacts with the amines of cellular proteins. In viable cells, cell membrane integrity prevents cell entry of the fluorescent compound, resulting in its reaction with only the cell-surface amines and the production of a low-intensity staining. However, in cells with compromised membranes, i.e., dying cells, the fluorescent reagent reacts with amines inside the cell and on its surface, producing intense fluorescent staining. In brief, $8 \times 10^{5}$ cells were resuspended in $1 \mathrm{ml}$ of $1 \mathrm{X}$ PBS, stained with $1 \mu \mathrm{l}$ of a 1:20 dilution of LIVE/DEAD red fluorescent reactive dye and incubated for $30 \mathrm{~min}$ at room temperature in the dark. The cell lines were then washed and resuspended in $1 \mathrm{ml} 1 \mathrm{X}$ PBS with $1 \%$ bovine serum albumin (Sigma-Aldrich; Merck $\mathrm{KGaA}$ ). Samples were analyzed with a BD FACSAria III flow cytometer system (BD Biosciences, Inc.), capturing at least 10,000 events for each sample. Data analysis was performed using Flowing Software version 2.5.1 (Turku Centre for Biotechnology).

Cell cycle assay. To analyze cell cycle profile changes in the pre-treatment assays, cell lines were harvested, washed with $1 \mathrm{X}$ PBS and fixed overnight at $-20^{\circ} \mathrm{C}$ with $1 \mathrm{ml}$ of ice-cold $70 \%$ ethanol. After fixation, the cells were washed with $1 \mathrm{ml}$ cold $1 \mathrm{X}$ PBS and resuspended in $250 \mu \mathrm{l}$ of $1 \mathrm{X}$ PBS. The cellular suspension was then incubated with $0.5 \mathrm{mg} / \mathrm{ml}$ RNAse A (Sigma-Aldrich; Merck KGaA) for $1 \mathrm{~h}$ at $37^{\circ} \mathrm{C}$. Finally, cells were stained with $10 \mu \mathrm{g} / \mathrm{ml}$ propidium iodide (Sigma-Aldrich; Merck KGaA) for $60 \mathrm{~min}$ on ice. Samples were analyzed using the BD FACSAria III flow cytometer system (BD Biosciences, Inc.), capturing at least 20,000 events for each sample. Cell cycle histograms were generated and analyzed using ModFit LT 3.2 software (Verity Software House).

Statistical analysis. Values are expressed as the mean \pm standard deviation. Differences between groups were analyzed by one-way analysis of variance followed by Tukey's multiple-comparisons test. Statistical analysis was performed using GraphPad Prism 7 software (version 5.01; GraphPad Software, Inc.). All data analyses were performed using results from at least three independent biological experiments. $\mathrm{P}<0.05$ was considered to indicate statistical significance.

\section{Results}

Cytotoxic effects of curcumin and arsenic in $E B V$-immortalized LCLs. Curcumin is a phytochemical with chemopreventive properties in normal cells but with cytotoxic effects in tumoral and immortalized cells. Thus, the cytotoxic effects of curcumin were evaluated in the EBV-immortalized lymphoblast cell line CL-49, including the measurement of the fluorescent intensity of the LIVE-DEAD viability dye through flow cytometry in concentration-response assays. A concentration-dependent increase was observed in the percentage of cell death after $24 \mathrm{~h}$ of incubation with $10 \mu \mathrm{M}$ $(20.1 \pm 2 \%)$ and $15 \mu \mathrm{M}(45.8 \pm 8.1 \%)$ curcumin (Fig. 1A). 
A

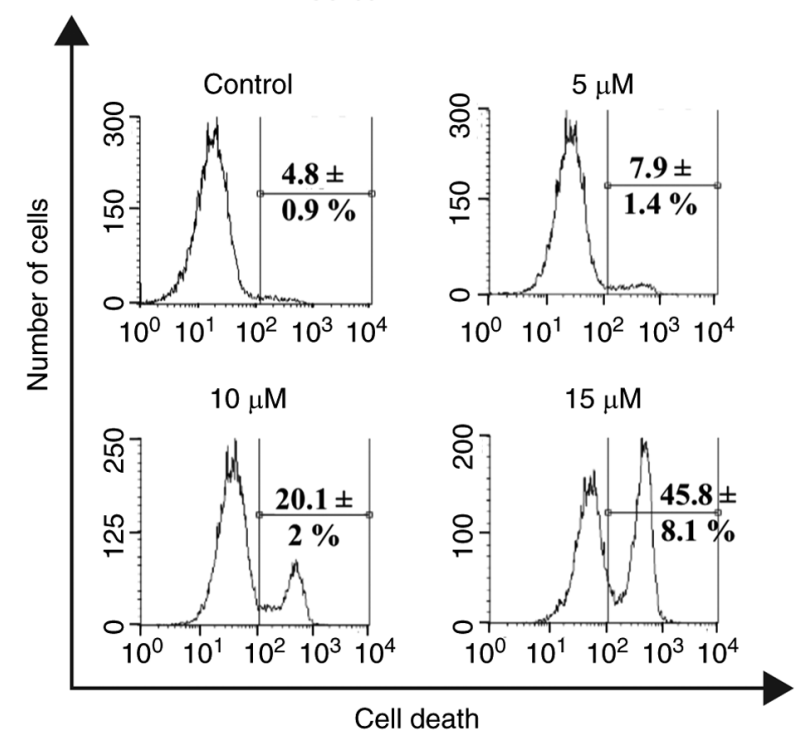

B

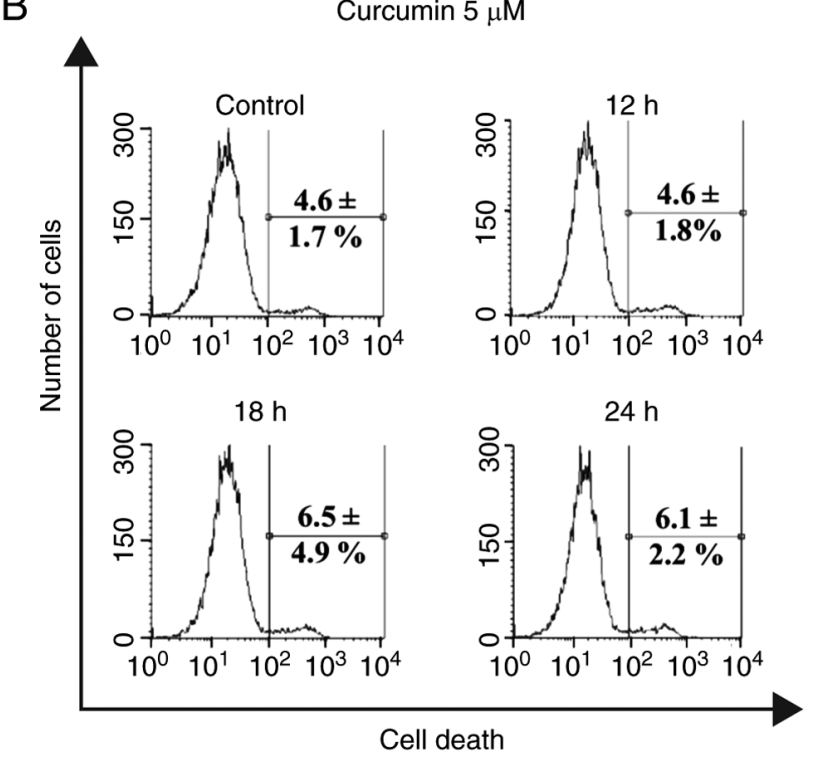

C

Arsenic $15 \mathrm{~h}$

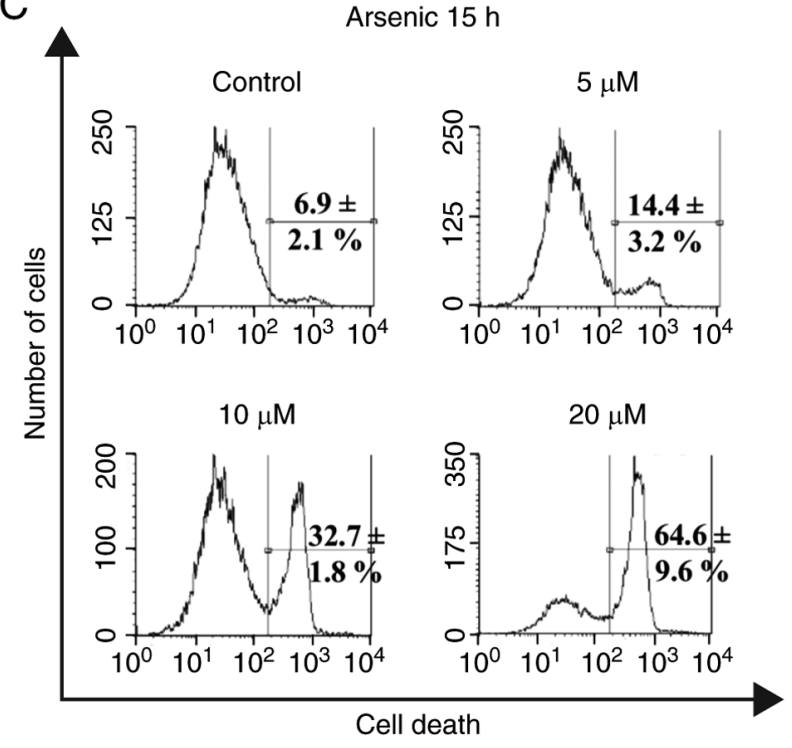

Figure 1. Cell death induced by curcumin and arsenic in an Epstein-Barr virus-immortalized lymphoblastoid cell line. CL-49 cells were treated with curcumin or iAs $\left(\mathrm{NaAsO}_{2}\right)$ and cell death was quantified by flow cytometry using the LIVE-DEAD assay. (A) CL-49 cells treated with 5,10 and $15 \mu \mathrm{M}$ curcumin for $24 \mathrm{~h}$. (B) The cell line was treated with $5 \mu \mathrm{M}$ curcumin for 12,18 or $24 \mathrm{~h}$. (C) Concentration-response assays after treatment with 5,10 and $20 \mu \mathrm{M}$ iAs for $15 \mathrm{~h}$. Representative histograms of at least three independent LIVE-DEAD assays are presented. The control group consisted of cell cultures treated with the respective vehicle for curcumin (DMSO) and iAs $\left(\mathrm{H}_{2} \mathrm{O}\right)$. iAs, inorganic arsenic.

By contrast, treatment with $5 \mu \mathrm{M}$ curcumin exhibited low toxicity compared with the vehicle control $(7.9 \pm 1.4$ vs $4.8 \pm 0.9 \%$; Fig. 1A). Accordingly, in time-response assays using $5 \mu \mathrm{M}$ curcumin, in comparison with the vehicle control $(4.6 \pm 1.7 \%)$, no significant increase in the percentage of cell death was obtained after incubation for $12 \mathrm{~h}(4.6 \pm 1.8 \%)$, $18 \mathrm{~h}(6.5 \pm 4.9 \%)$ or $24 \mathrm{~h}(6.1 \pm 2.2 \%)$ (Fig. 1B). These results suggested that $5 \mu \mathrm{M}$ curcumin had no toxic effects on the CL-49 cell line.

The cytotoxic effect of iAs exposure for $15 \mathrm{~h}$ was then evaluated in CL-49 cells using concentration-response curves. This incubation time was selected based on the consideration of using a curcumin pre-treatment time of $9 \mathrm{~h}$, which together with iAs incubation time for $15 \mathrm{~h}$ covers the LCL cell cycle of $\sim 24 \mathrm{~h}$. As expected, iAs treatment increased the levels of cell death in a concentration-dependent manner, starting at a concentration of as low as $5 \mu \mathrm{M}(14.4 \pm 3.2 \%)$ and up to $20 \mu \mathrm{M}(64.6 \pm 9.6 \%)$, which was the highest concentration used (Fig. 1C). The intermediate concentration of $10 \mu \mathrm{M}$ iAs was used for further curcumin pre-treatment assays because this concentration may not be associated with massive necrotic cell death events, as may occur with a highly toxic concentration of $20 \mu \mathrm{M}$. In addition, the $10-\mu \mathrm{M}$ concentration of iAs is equivalent to a high level of human exposure through iAs-contaminated drinking water $(750 \mu \mathrm{g} / \mathrm{l})$.

Curcumin enhances arsenic-induced toxicity in EBV-immortalized lymphocytes. To explore the effect of curcumin on iAs-induced toxicity on CL-49 cells, levels of cell death were analyzed after treatment with $10 \mu \mathrm{M}$ iAs for 


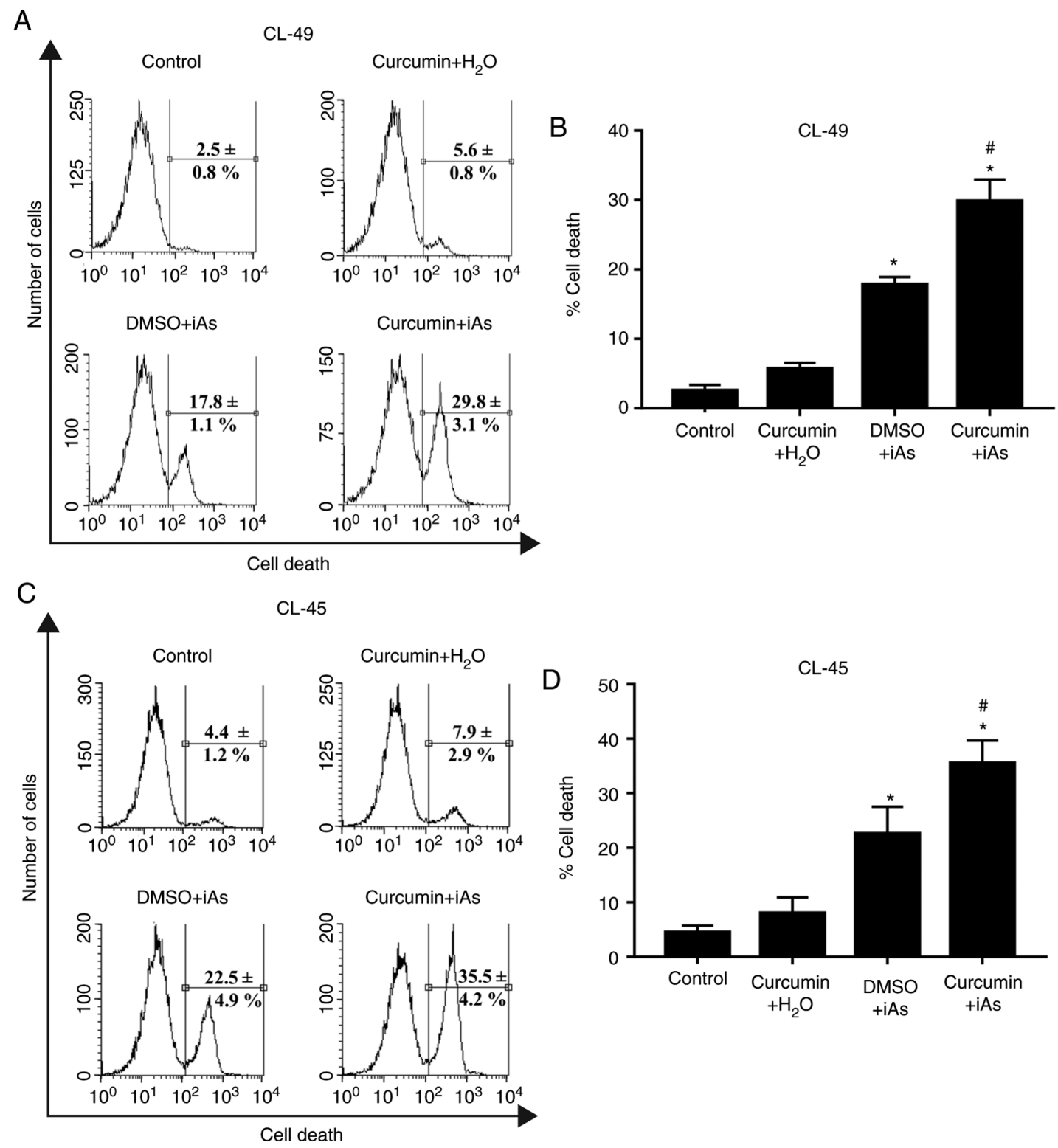

Figure 2. Curcumin sensitizes Epstein-Barr virus-immortalized lymphoblastoid cell lines to the toxicity of arsenic. Cell death in the CL-45 and CL-49 cell lines treated with $5 \mu \mathrm{M}$ curcumin for $9 \mathrm{~h}$ prior to treatment with $10 \mu \mathrm{M}$ iAs $\left(\mathrm{NaAsO}_{2}\right)$ for $15 \mathrm{~h}$ was quantified. (A) Representative histograms of at least three independent experiments to quantify cell death in CL-49 cells measured by flow cytometry using LIVE-DEAD assays. (B) Bar graph presenting the quantified results for panel A. (C) Representative histograms of at least three independent experiments to quantify cell death in CL-45 cells measured by flow cytometry using LIVE-DEAD assays. (D) Bar graph presenting the quantified results for panel C. The control group was treated with curcumin vehicle (DMSO) for $9 \mathrm{~h}$ and iAs vehicle $\left(\mathrm{H}_{2} \mathrm{O}\right)$ for a further $15 \mathrm{~h}$. Values are expressed as the mean \pm standard deviation. ${ }^{~} \mathrm{P}<0.05$, treated groups vs. vehicle control group; ${ }^{*} \mathrm{P}<0.05$, Curcumin + iAs vs. DMSO + iAs. iAs, inorganic arsenic.

$15 \mathrm{~h}$ with or without pre-treatment with $5 \mu \mathrm{M}$ curcumin for $9 \mathrm{~h}$. The percentage of cell death increased from $\sim 18 \%$ in the iAs-treated cultures in the absence of curcumin pre-treatment to almost $30 \%$ in CL-49 cells incubated with curcumin prior to iAs treatment (Fig. 2A and B). As expected, pre-treatment with $5 \mu \mathrm{M}$ curcumin followed by incubation with iAs vehicle $\left(\mathrm{H}_{2} \mathrm{O}\right)$ resulted in a non-significant increase in cellular toxicity in comparison with the vehicle control ( $5.6 \pm 0.8$ vs. $2.5 \pm 0.8 \%$; Fig. 2A and B). To rule out any cell line-specific effect on the drug-sensitizing capacity of curcumin, the same experimental conditions were applied in a second EBV-positive LCL (CL-45 cells) derived from an independent healthy donor. A previous study by our group suggested that treatment of CL-45 cells with $5 \mu \mathrm{M}$ curcumin for $24 \mathrm{~h}$ did not significantly increase cell death (19). Similar to the effect on CL-49 cells, the CL-45 cell line treated with $10 \mu \mathrm{M}$ iAs after incubation with curcumin vehicle (DMSO) exhibited lower levels of cell death than those observed in cell cultures treated with $5 \mu \mathrm{M}$ curcumin prior to iAs incubation (22.5 \pm 4.9 vs. $35.5 \pm 4.2 \%$; Fig. $2 \mathrm{C}$ and D). These results suggested that curcumin sensitizes EBV-immortalized LCLs to iAs-related toxicity.

Cytostatic effect of curcumin and arsenic on LCLs. Next, alterations in cell cycle progression induced by curcumin sensitization to iAs toxicity were examined. As the cytotoxic effect of curcumin on CL-49 and CL-45 was similar and both cell lines were obtained from healthy individuals using the same strain of EBV, it was decided to evaluate the cytostatic 


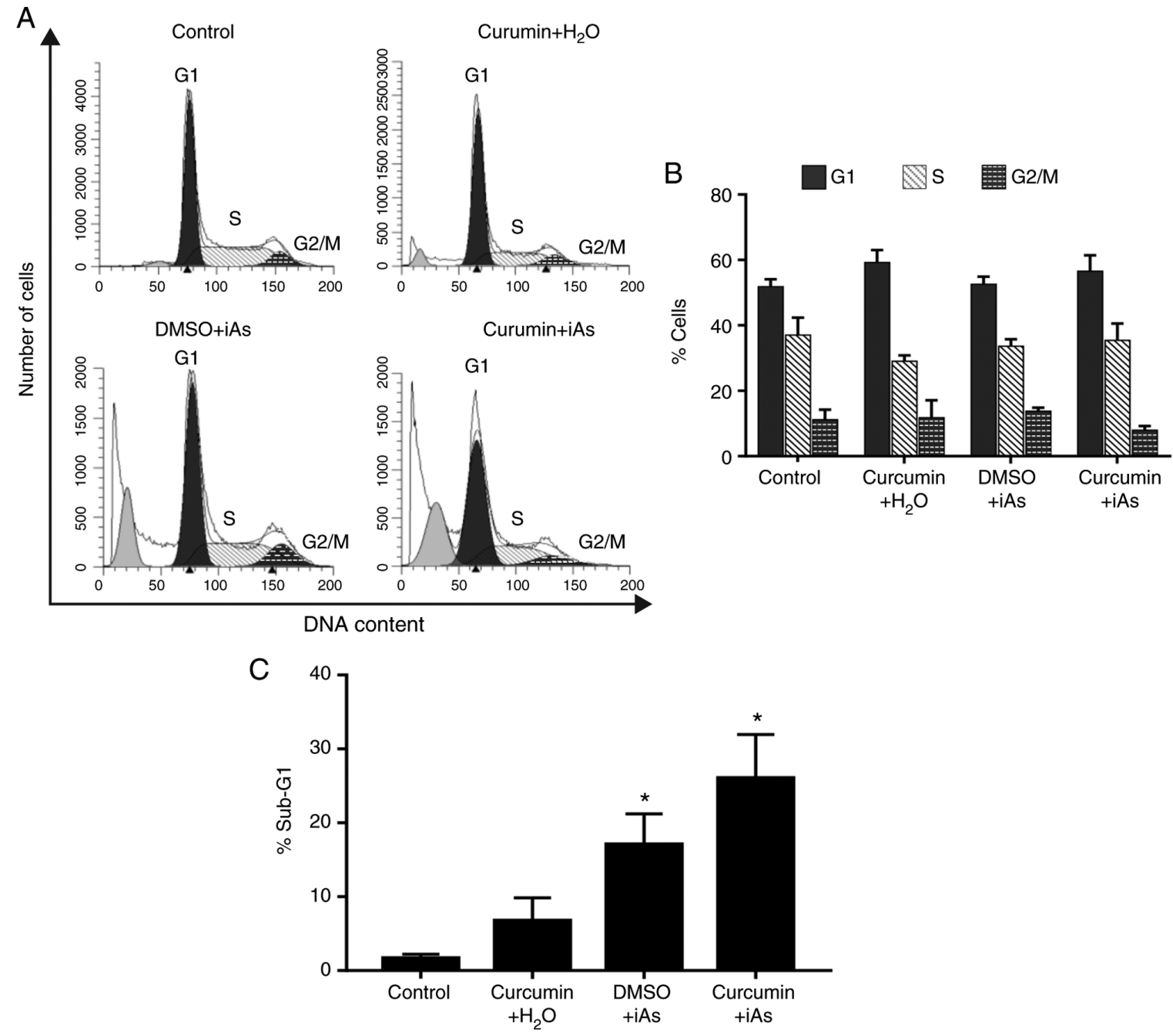

Figure 3. Cytostatic effect of the individual and combined treatments with arsenic and curcumin in an Epstein-Barr virus-immortalized lymphoblastoid cell line. CL-49 cells were treated with vehicle controls for the test compounds (control group), $10 \mu \mathrm{M}$ iAs $\left(\mathrm{NaAsO}_{2}\right), 5 \mu \mathrm{M}$ curcumin or curcumin pre-treatment followed by incubation with iAs (Curcumin + iAs). (A) Histograms representative of the cell cycle profile of CL-49 cells. (B) Bar graph presenting the quantified cell populations in the cell cycle phases from panel A. (C) Bar graph presenting the percentage of CL-49 cells in sub-G1 phase observed in panel A. Values are expressed as the mean \pm standard deviation. ${ }^{*} \mathrm{P}<0.05$, treated groups vs. vehicle control group. iAs, inorganic arsenic.

effects of curcumin only in CL-49 cells. The results suggested that treatment with $5 \mu \mathrm{M}$ curcumin and iAs vehicle $\left(\mathrm{H}_{2} \mathrm{O}\right)$, compared with the vehicle control, induced a significant accumulation of cells in G1 phase (59.2 \pm 3.8 vs. $51.8 \pm 2.3 \%)$, without any evident changes in the sub-G1 population (Fig. 3). In the group treated with iAs alone, no apparent effect on cell cycle progression was observed, while a significant increase in sub-G1 cells was detected in comparison with the vehicle group (17.1 \pm 4.2 vs. $1.6 \pm 0.6 \%$; Fig. 3 ).

Of note, CL-49 cells treated with curcumin followed by iAs treatment exhibited a not significant increase in the number of cells in the G1 and S phases in comparison with curcumin vehicle and iAs treatment (G1: $56.5 \pm 4.9$ vs. $52.5 \pm 2.3 \%$; S: $35.4 \pm 5.1$ vs. $33.7 \pm 2.1 \%$; Fig. $3 \mathrm{~A}$ and B). Consistent with the previous results for cell death, the sub-G1 phase levels in the curcumin + iAs group increased significantly with respect to cell cultures treated only with iAs (26.0 \pm 5.9 vs. $17.1 \pm 4.2 \%$; Fig. 3 C). These results indicated that curcumin may enhance iAs-related toxicity, possibly through cytostatic effects.

\section{Discussion}

Hydroarsenicism is a major health issue worldwide, as 100 million individuals are chronically exposed to this pollutant (22). The natural compound curcumin has emerged as an important alternative strategy for diminishing the toxic effects caused by arsenic exposure $(8,9,11,12,23)$. However, previous studies documented the cytotoxic effects of curcumin in EBV immortalized lymphoblastoid cells lines and in cell lines derived from tumors associated with chronic EBV infection (15-19). Considering the high prevalence of EBV infection in human populations, the use of this phytochemical as a chemo-preventive compound may be associated with different side effects on human health.

Thus, in the present study, EBV-immortalized lymphocytes were used as an experimental model to evaluate the effect of latent EBV infection on the chemopreventive properties of curcumin against iAs. First, a significant increase in CL-49 cell death was observed after individual treatment with curcumin or iAs, at concentrations ranging from 10 to 
$15 \mu \mathrm{M}$ in the case of curcumin and from 5 to $20 \mu \mathrm{M}$ for iAs. Previous studies have described the induction of cell death in EBV-immortalized LCLs treated with curcumin in the range of 15 to $20 \mu \mathrm{M}(18,19)$. Furthermore, iAs-related induction of cell death by autophagy in LCLs and by apoptosis in EBV-positive Burkitt's lymphoma cells has been described at similar concentrations $(24,25)$.

When the protective effect of non-toxic concentrations of curcumin against iAs was evaluated in EBV-immortalized lymphocytes, higher levels of cell death were detected in cell cultures treated with curcumin prior to incubation with iAs than after treatment with iAs alone. This result is in clear contradiction with the chemopreventive effect exerted by curcumin against iAs-induced genotoxic damage and toxicity reported in different cellular and animal models (10,21,26-28). In addition, pre-treatment with curcumin enhanced iAs-related alterations in cell cycle progression, provoking a not significant arrest in G1 and $\mathrm{S}$ phases and a reduction of cells in $\mathrm{G} 2 / \mathrm{M}$ phase.

In the flow cytometry assays, the presence of a population of sub-G1 cells was observed after iAs treatment, with or without curcumin pre-treatment (Fig. 3A), which is indicative of apoptosis. iAs promotes genotoxic damage in LCLs and activates apoptosis with caspase processing in EBV-positive Burkitt's lymphoma cells $(25,29,30)$. However, it was reported that autophagy is the predominant type of cell death induced by iAs in human lymphocytes (24). Thus, further studies are necessary to conclusively determine the type of cell death induced by curcumin and iAs treatment in LCLs.

Previous studies also have described a delayed progression from $\mathrm{S}$ to $\mathrm{M}$ phase in circulating lymphocytes extracted from individuals chronically exposed to iAs through drinking water $(31,32)$. Similarly, iAs concentrations ranging from 5 to $10 \mu \mathrm{M}$ induce $\mathrm{S}$-phase accumulation in cell lines derived from bladder and breast carcinomas and in myeloid leukemia cell lines after treatments for 12 to $24 \mathrm{~h}$ (33-36). Of note, iAs-treated cells exhibit high caspase activity (35).

In the case of curcumin, its anti-proliferative effects in EBV-immortalized LCLs have been reported to be predominantly exerted through causing G1-phase arrest. However, in cell lines derived from monocytic leukemia and gallbladder, breast and colorectal cancer cells, the phytochemical was observed to induce arrest in $\mathrm{S}$ phase (37-41). In addition, curcumin causes DNA damage in human lymphocytes $(42,43)$ and activates apoptosis with phosphatidylserine exposure, cytochrome $\mathrm{C}$ release, poly(ADP-ribose) polymerase (PARP) cleavage and DNA damage in LCLs and EBV-positive B-lymphoma cell lines $(17,18,44,45)$. Thus, in the current model, curcumin pretreatment increased the genotoxic properties of iAs promoting an initial arrest in the cell cycle, followed by induction of apoptosis.

The chemosensitizing effects of curcumin in EBV-positive cells may be explained by its capacity to modulate the EBV life cycle. Curcumin reduces levels of Epstein-Barr nuclear antigen 1, a critical protein for viral latency maintenance, promoting cell cycle arrest and apoptosis of EBV-nasopharyngeal carcinoma cells (46). Similarly, a previous study indicated that curcuminoids promote EBV lytic cycle reactivation, increasing the cell death of gastric and nasopharyngeal cell lines when combined with other lytic activators such as gemcitabine and valproic acid (15).

Of note, the concentration of curcumin used in the present study was significantly lower than that associated with adverse effects on human health. For instance, a study evaluating the effect of curcumin on DNA damage repair potential used an intervention of $500 \mathrm{mg}(1.36 \mathrm{mM})$ twice a day for 3 months in 66 healthy volunteers without any apparent adverse effects on their health (12). Another study demonstrated the safety of ingesting increasing concentrations of a commercial curcumin formulation (C3 Complex $\left.{ }^{\mathrm{TM}}\right)$ of up to $12,000 \mathrm{mg}(32.6 \mathrm{mM})$ in healthy individuals, revealing minimal toxicity that did not appear to be dose-related. The adverse health effects of the highest doses were headache and diarrhea, both classified as grade I according to National Cancer Institute, Common Toxicity Criteria version 2.0 (47).

The present study, as far as may be discerned, was the first to assess the chemosensitizing capacity of curcumin to iAs toxicity in LCLs. However, the present study had several limitations. For instance, the type of cell death (e.g. necrosis or apoptosis) observed after the different treatments (i.e. curcumin, iAs and curcumin plus iAs) was not characterized by using differential assays such as Annexin V/PI staining, caspase processing, PARP cleavage or DNA fragmentation. In addition, evaluation of the alteration of RNA or protein levels of cell cycle regulators was also lacking. This indicates the necessity of characterizing the specific type of cell death and the cellular mechanisms activated by curcumin pre-treatment before LCLs are exposed to iAs. In the same sense, the cell cycle alterations associated with the sensitizing effects of curcumin should be evaluated. Further studies are warranted to test the sensitizing effect of this phytochemical to iAs in primary lymphocytes and other EBV-infected cells.

In conclusion, the results of the present study indicated that curcumin pre-treatment sensitized EBV-positive LCLs to iAs toxicity. Thus, further studies analyzing the use of curcumin as a strategy for reducing iAs toxicity in individuals with chronic EBV infection are required.

\section{Acknowledgements}

The authors would like to acknowledge Mrs. Linda Nelly Patiño Uriostegui (National Institute of Genomic Medicine, Flow cytometry Lab; Mexico) and Mr. José Luis Cruz-Colin (National Institute of Genomic Medicine, Clinic Research; Mexico) for their valuable technical assistance.

\section{Funding}

This work was supported by a grant from Secretary of Public Education-National Council for Science and Technology (SEP-CONACYT; grant no. 243587) and from the National Institute of Genomic Medicine (INMEGEN; grant no. CON31/2015). MMC received a fellowship from the National System of Researchers in Mexico.

\section{Availability of data and materials}

The datasets used and/or analyzed during the present study are available from the corresponding author on reasonable request. 


\section{Authors' contributions}

Conceived and designed the experiments: EJC, AHZ and MMC. Performed the experiments: MMC and GCR. Wrote the manuscript: EJC, AHZ and MMC. Coordinated and facilitated the project: EJC. EJC and AHZ confirmed the authenticity of the raw data. All authors have read and approved the final manuscript.

\section{Ethics approval and consent to participate}

Not applicable.

\section{Patient consent for publication}

Not applicable.

\section{Competing interests}

The authors declare that they have no competing interests.

\section{References}

1. Chung J, Yu S and Hong Y: Environmental source of arsenic exposure. J Prev Med Public Health 47: 253-257, 2014.

2. Shaji E, Santosh M, Sarath KV, Prakash Pranav, Deepchand V and Divya BD: Arsenic contamination of groundwater: A global synopsis with focus on the Indian peninsula. Geosci Front 12 101079, 2021.

3. Sinha D and Prasad P: Health effects inflicted by chronic low-level arsenic contamination in groundwater: A global public health challenge. J Appl Toxicol 40: 87-131, 2020.

4. Carlin DJ, Naujokas MF, Bradham KD, Cowden J, Heacock M, Henry HF, Lee JS, Thomas DJ, Thompson C, Tokar EJ, et al: Arsenic and environmental health: State of the science and future research opportunities. Environ Health Perspect 124: 890-899, 2016

5. Amadi CN, Offor SJ, Frazzoli C and Orisakwe OE: Natural antidotes and management of metal toxicity. Environ Sci Pollut Res Int 26: 18032-18052, 2019.

6. Hewlings SJ and Kalman DS: Curcumin: A review of its effects on human health. Foods 6: 92, 2017.

7. Shah BH, Nawaz Z, Pertani SA, Roomi A, Mahmood H, Saeed SA and Gilani AH: Inhibitory effect of curcumin, a food spice from turmeric, on platelet-activating factor- and arachidonic acid-mediated platelet aggregation through inhibition of thromboxane formation and $\mathrm{Ca} 2+$ signaling. Biochem Pharmacol 58: 1167-1172, 1999

8. Zhao R, Yang B, Wang L, Xue P, Deng B, Zhang G, Jiang S, Zhang M, Liu M, Pi J and Guan D: Curcumin protects human keratinocytes against inorganic arsenite-induced acute cytotoxicity through an NRF2-dependent mechanism. Oxid Med Cell Longev 2013: 412576, 2013.

9. Hosseinzadehdehkordi M, Adelinik A and Tashakor A: Dual effect of curcumin targets reactive oxygen species, adenosine triphosphate contents and intermediate steps of mitochondria-mediated apoptosis in lung cancer cell lines. Eur J Pharmacol 769: 203-210, 2015.

10. Tiwari $\mathrm{H}$ and Rao MV: Curcumin supplementation protects from genotoxic effects of arsenic and fluoride. Food Chem Toxicol 48 1234-1238, 2010.

11. Biswas J, Sinha D, Mukherjee S, Roy S, Siddiqi M and Roy M: Curcumin protects DNA damage in a chronically arsenic-exposed population of West Bengal. Hum Exp Toxicol 29: 513-524, 2010

12. Roy M, Sinha D, Mukherjee S and Biswas J: Curcumin prevents DNA damage and enhances the repair potential in a chronically arsenic-exposed human population in West Bengal, India. Eur J Cancer Prev 20: 123-131, 2011.

13. Ali AS, Al-Shraim M, Al-Hakami AM and Jones IM: Epstein-Barr virus: Clinical and epidemiological revisits and genetic basis of oncogenesis. Open Virol J 9: 7-28, 2015.
14. Geng L and Wang X: Epstein-Barr virus-associated lymphoproliferative disorders: Experimental and clinical developments. Int J Clin Exp Med 8: 14656-14671, 2015.

15. Ramayanti O, Brinkkemper M, Verkuijlen SAWM, Ritmaleni L, Go ML and Middeldorp JM: Curcuminoids as EBV lytic activators for adjuvant treatment in EBV-positive carcinomas. Cancers (Basel) 10: 89, 2018.

16. Mackenzie GG, Queisser N, Wolfson ML, Fraga CG, Adamo AM and Oteiza PI: Curcumin induces cell-arrest and apoptosis in association with the inhibition of constitutively active NF-kappaB and STAT3 pathways in Hodgkin's lymphoma cells. Int J Cancer 123: 56-65, 2008.

17. Li ZX, Ouyang KQ, Jiang X, Wang D and Hu Y: Curcumin induces apoptosis and inhibits growth of human Burkitt's lymphoma in xenograft mouse model. Mol Cells 27: 283-289, 2009.

18. Ranjan D, Johnston TD, Reddy KS, Wu G, Bondada S and Chen C: Enhanced apoptosis mediates inhibition of EBV-transformed lymphoblastoid cell line proliferation by curcumin. J Surg Res 87: 1-5, 1999.

19. Méndez-García LA, Martínez-Castillo M, Villegas-Sepúlveda N, Orozco L and Córdova EJ: Curcumin induces p53-independent inactivation of Nrf2 during oxidative stress-induced apoptosis. Hum Exp Toxicol 38: 951-961, 2019.

20. Córdova EJ, Martínez-Hernández A, Uribe-Figueroa L, Centeno F, Morales-Marín M, Koneru H, Coleman MA and Orozco L: The NRF2-KEAP1 pathway is an early responsive gene network in arsenic exposed lymphoblastoid cells. PLoS One 9: e88069, 2014.

21. Morales-Marin ME, Cordova EJ, Centeno F, Martínez-Hernández A, Méndez-García A, Molina B, Frías S and Orozco L: NFE2L2 gene variants and arsenic susceptibility: A lymphoblastoid model. J Toxicol Environ Health A 78: 628-634, 2015.

22. Shankar S, Shanker U and Shikha: Arsenic contamination of groundwater: A review of sources, prevalence, health risks, and strategies for mitigation. ScientificWorldJournal 2014: 304524, 2014.

23. Mukherjee S, Roy M, Dey S and Bhattacharya RK: A mechanistic approach for modulation of arsenic toxicity in human lymphocytes by curcumin, an active constituent of medicinal herb curcuma longa linn. J Clin Biochem Nutr 41: 32-42, 2007.

24. Bolt AM, Byrd RM and Klimecki WT: Autophagy is the predominant process induced by arsenite in human lymphoblastoid cell lines. Toxicol Appl Pharmacol 244: 366-373, 2010.

25. Zebboudj A, Maroui MA, Dutrieux J, Touil-Boukoffa C, Bourouba M, Chelbi-Alix MK and Nisole S: Sodium arsenite induces apoptosis and Epstein-Barr virus reactivation in lymphoblastoid cells. Biochimie 107: 247-256, 2014.

26. Khan S, Vala JA, Nabi SU, Gupta G, Kumar D, Telang AG and Malik JK: Protective effect of curcumin against arsenic-induced apoptosis in murine splenocytes in vitro. J Immunotoxicol 9: 148-159, 2012.

27. El-Demerdash FM, Yousef MI and Radwan FME: Ameliorating effect of curcumin on sodium arsenite-induced oxidative damage and lipid peroxidation in different rat organs. Food Chem Toxicol 47: 249-254, 2009.

28. Gao S, Duan X, Wang X, Dong D, Liu D, Li X, Sun G and Li B: Curcumin attenuates arsenic-induced hepatic injuries and oxidative stress in experimental mice through activation of Nrf2 pathway, promotion of arsenic methylation and urinary excretion. Food Chem Toxicol 59: 739-747, 2013.

29. Rasmussen RE and Menzel DB: Variation in arsenic-induced sister chromatid exchange in human lymphocytes and lymphoblastoid cell lines. Mutat Res 386: 299-306, 1997.

30. Guillamet E, Creus A, Ponti J, Sabbioni E, Fortaner S and Marcos R: In vitro DNA damage by arsenic compounds in a human lymphoblastoid cell line (TK6) assessed by the alkaline Comet assay. Mutagenesis 19: 129-135, 2004.

31. Ostrosky-Wegman P, Gonsebatt ME, Montero R, Vega L, Barba H, Espinosa J, Palao A, Cortinas C, García-Vargas G and del Razo LM: Lymphocyte proliferation kinetics and genotoxic findings in a pilot study on individuals chronically exposed to arsenic in Mexico. Mutat Res 250: 477-482, 1991.

32. Gonsebatt ME, Vega L, Montero R, Garcia-Vargas G, Del Razo LM, Albores A, Cebrian ME and Ostrosky-Wegman P: Lymphocyte replicating ability in individuals exposed to arsenic via drinking water. Mutat Res 313: 293-299, 1994. 
33. Hernández-Zavala A, Córdova E, Del Razo LM, Cebrián ME and Garrido E: Effects of arsenite on cell cycle progression in a human bladder cancer cell line. Toxicology 207: 49-57, 2005.

34. Pozo-Molina G, Ponciano-Gómez A, Rivera-González GC, Hernández-Zavala A and Garrido E: Arsenic-induced S phase cell cycle lengthening is associated with ROS generation, p53 signaling and CDC25A expression. Chem Biol Interact 238: $170-179,2015$

35. McCollum G, Keng PC, States JC and McCabe MJ Jr: Arsenite delays progression through each cell cycle phase and induces apoptosis following G2/M arrest in U937 myeloid leukemia cells. J Pharmacol Exp Ther 313: 877-887, 2005.

36. Lehmann GM and McCabe MJ: Arsenite slows S phase progression via inhibition of cdc25A dual specificity phosphatase gene transcription. Toxicol Sci 99: 70-78, 2007.

37. Zhu GH, Dai HP, Shen Q, Ji O, Zhang Q and Zhai YL: Curcumin induces apoptosis and suppresses invasion through MAPK and MMP signaling in human monocytic leukemia SHI-1 cells. Pharm Biol 54: 1303-1311, 2016.

38. Liu TY, Tan ZJ, Jiang L, Gu JF, Wu XS, Cao Y, Li ML, Wu KJ and Liu YB: Curcumin induces apoptosis in gallbladder carcinoma cell line GBC-SD cells. Cancer Cell Int 13: 64, 2013.

39. Saleh EM, El-awady RA, Eissa NA and Abdel-Rahman WM: Antagonism between curcumin and the topoisomerase II inhibitor etoposide: A study of DNA damage, cell cycle regulation and death pathways. Cancer Biol Ther 13: 1058-1071, 2012.

40. Lu JJ, Cai YJ and Ding J: Curcumin induces DNA damage and caffeine-insensitive cell cycle arrest in colorectal carcinoma HCT116 cells. Mol Cell Biochem 354: 247-252, 2011.
41. Xiang L, He B, Liu Q, Hu D, Liao W, Li R, Peng X, Wang Q and Zhao G: Antitumor effects of curcumin on the proliferation, migration and apoptosis of human colorectal carcinoma HCT-116 cells. Oncol Rep 44: 1997-2008, 2020.

42. Błasiak J, Trzeciak A, Małecka-Panas E, Drzewoski J, Iwanienko T, Szumiel I and Wojewódzka M: DNA damage and repair in human lymphocytes and gastric mucosa cells exposed to chromium and curcumin. Teratog Carcinog Mutagen 19: 19-31, 1999.

43. Sebastià N, Soriano JM, Barquinero JF, Villaescusa JI, Almonacid M, Cervera J, Such E, Silla MA and Montoro A: In vitro cytogenetic and genotoxic effects of curcumin on human peripheral blood lymphocytes. Food Chem Toxicol 50: 3229-3233, 2012.

44. Chen C, Johnston TD, Jeon H, Gedaly R, McHugh PP, Burke TG and Ranjan D: An in vitro study of liposomal curcumin: Stability, toxicity and biological activity in human lymphocytes and Epstein-Barr virus-transformed human B-cells. Int J Pharm 366: 133-139, 2009.

45. Han SS, Chung ST, Robertson DA, Ranjan D and Bondada S: Curcumin causes the growth arrest and apoptosis of B cell lymphoma by downregulation of egr-1, C-myc, Bcl-XL, NF-kappaB, and p53. Clin Immunol 93: 152-161, 1999.

46. Liu L, Yang J, Ji W and Wang C: Curcumin inhibits proliferation of epstein-barr virus-associated human nasopharyngeal carcinoma cells by inhibiting EBV nuclear antigen 1 expression. BioMed Res Int 2019: 8592921, 2019.

47. Lao CD, Ruffin MT IV, Normolle D, Heath DD, Murray SI, Bailey JM, Boggs ME, Crowell J, Rock CL and Brenner DE: Dose escalation of a curcuminoid formulation. BMC Complement Altern Med 6: 10, 2006 